\title{
Possibility of using combined transplantation of multipotent mesenchymal stromal cells and hepatic stellate cells to activate reparative liver regeneration in mature and old organism
}

\author{
Irina Maklakova ${ }^{1,2 *}$, Dmitry Grebnev ${ }^{1,2}$, Victoria Vakhrusheva $^{1}$, and Ekaterina Petrunina ${ }^{3}$ \\ ${ }^{1}$ FSBEI HE Ural State Medical University Ministry of Health of the Russian Federation, 620028, \\ Yekaterinburg, Russian Federation \\ ${ }^{2}$ SAHI SO "Institute of Medical Cell Technologies", 620026 Yekaterinburg, Russian Federation \\ ${ }^{3}$ Ural Research Institute of Phthisiopulmonology - branch of the Federal State Institution "National \\ Medical Research Center of Phthisiopulmonology and Infectious Diseases" of the Ministry of Health \\ of Russia, 620039, Yekaterinburg, Russian Federation
}

\begin{abstract}
The aim of the study was to examine the effect of combined transplantation of multipotent mesenchymal stromal (MMSC) and hepatic stellate (HSC) cells on liver regeneration after resection. Research has been carried out on laboratory animals of mature and old age. After the subtotal resection of the liver, MMSC and HSC were introduced in the tail vein in the amount of 4 million cl/ $\mathrm{kg}$ of body weight and 9 million $\mathrm{cl} / \mathrm{kg}$ of body weight respectively. Evaluation of reparative liver regeneration was performed on the 1st, 3rd, 7th days after subtotal liver resection. Features of reparative liver regeneration in mature and old organism were revealed. In mature organism against the background of combined cell transplantation, regeneration activation is achieved by increasing cellular and intracellular regeneration mechanisms. In this case, the old organism responds to cell transplantation by activating only intracellular mechanisms. In both age groups, decreased mutagenesis and inhibition of programmed cell death against the background of MMSC cotransplantation and HSC were observed.
\end{abstract}

\section{Introduction}

Finding alternative ways to activate liver regeneration under conditions of its damage in aging is a pressing problem. It is known that compensatory-adaptive capabilities, cells ability to homing, differentiation - all of it is decreased in the old organism, which determines significant changes in the rate of reparative regeneration $[1,2,3]$. In aging, there is a decrease in functional activity of the liver. Due to this, an active search for new ways to restore the structural and functional state of the liver in the old body after its damage is being carried out. One of the tools in this regard may be the use of biomedical cell products. Multipotent mesenchymal stromal cells (MMSC) are self-renewing cells that can be found in almost all postnatal organs and tissues including the liver [4]. Much

\footnotetext{
${ }^{*}$ Corresponding author: makliu@mail.ru
} 
progress has been made in the field of MMSC-dependent regeneration and immunomodulation of the liver over the past decade. Because of their ability to produce biologically active substances and their immunomodulatory characteristics, MMSC introduction is considered a promising solution for acute hepatic insufficiency therapy [5, 6]. Also, a significant role in liver regeneration is given to hepatic stellate cells (HSC). These cells form the microenvironment of hepatocytes, forming collagen (IV, VI, XIV types), glycoproteins, proteoglycans. During liver resection, HSC produces mitogens for hepatocytes - hepatocytic growth factor, SCF, epimorphine, pleiotrophin [7, 8]. MMSCs are known to be capable of producing SCF that contributes to increasing proliferative activity of HSC [9]. Given the biological features of the interaction between MMSC and HSC, it seems promising to use combined MMSC and HSC transplantation to activate liver regeneration after its subtotal resection.

\section{Materials and methods}

Experiments were performed on 84 white male laboratory mice aged 7-8 months, with weight of 25-27 g and 84 male mice 16-17 months old, 30-32 g of weight. MMSC was released from the placenta chorion of 5 female laboratory mice aged $3-4$ months, gestation period -18 days.

All experiments, care and management of animals were carried out in accordance with Directive No. 63 dated September 22, 2010 of the Presidency and the Parliament of Europe "On the Protection of Animals Used for Scientific Research" and the Order of the Ministry of Health of the Russian Federation No. 267 of June 19, 2003 "On approval of the rules of laboratory practice". The research is approved by the local ethical committee of FSBEI HE "Ural State Medical University" Protocol No. 8 dated 20.10.2017.

The mononuclear cell fraction was obtained by sequential mechanical and enzymatic (solution of accutase (Millipore, USA)) processing of placenta tissue. The HSC release was carried out by collagenase-pronase liver perfusion method followed by cell separation in histogenesis density gradient. MMSC was cultivated under $\mathrm{CO}_{2}$ conditions - an incubator (Termo Scientific, USA) at a temperature of $37^{\circ} \mathrm{C}$ with $5 \%$ carbon dioxide content and $90 \%$ humidity. The MMSC of the third passage was used for transplantation to laboratory animals. The HSC introduction was carried out immediately after cells isolation. MMSC identification was carried out using the Mesenchymal Stem Cell Characterization Kit (Millipore, USA) containing positive (antibodies to integrin $\beta 1$, CD 54, collagen type I and libronectin) and negative markers (antibodies to CD 14, CD 45). The study of isolated cells' functional properties was carried out by directed differentiation of the obtained culture in directions characteristic of MMSC - in adipocytic and osteogenic. The HSC identification was performed on the Beckman Coulter Navios flow cytometer by evaluating HSC endogenous retinoid fluorescence. The cell viability was determined by supravital coloration with a solution of tripan blue and amounted to $95-97 \%$.

Experimental group animals were intravenously injected with MMSC and HSC at a dose of 4 million cells $/ \mathrm{kg}$ and 9 million cells $/ \mathrm{kg}$ respectively, suspended in $0.2 \mathrm{ml} 0.9 \%$ $\mathrm{NaCl}$ solution. The control group animals were injected with $0.9 \%$ solution of $\mathrm{NaCl}-0.2$ $\mathrm{ml}$ intravenously. Intravenous introductions were carried out once, 1 hour after subtotal resection. Resection of $2 / 3$ of the liver in laboratory mice was performed according to $\mathrm{C}$. Mitchell and H. Willenbring [10]. The influence of MMSC and HSC combined transplantation on biochemical parameters of peripheral blood and morphometric liver parameters under physiological conditions and after subtotal resection on the 1st, 3rd, 7th day were studied. The animals were taken out of the experiment with decapitation under mild ethereal anesthesia. 
Histological liver cuts 3-5 $\mu \mathrm{m}$ thick stained with hematoxylin-eosin were made. For morphometric data analysis a computer program of image analysis (Biovision, Russia) was used.

The following liver morphometric indicators were evaluated: hepatocyte count per 1 $\mathrm{mm}^{2}$, hepatocyte area, hepatocyte nucleus area, hepatocyte cytoplasm area, nuclear cytoplasmic index (NCI), number of binuclear hepatocytes per $1 \mathrm{~mm}^{2}$, mitotic index (MI), apoptotic index (AI). Verification of apoptosis severity was carried out using the ApopTag® Peroxidase In Situ Oligo Ligation (ISOL) (Millipore, USA) method.

Reliability of differences in the compared samples was carried out using the nonparametric (rank) Mann-Whitney method. Statistical data processing was carried out using the SPSS Statistics software package (version 17.0).

\section{Results and discussions}

When studying morphometric liver parameters on the 1st day after liver resection in mature and old laboratory animals on the combined MMSC and HSC transplantation background, a decrease in apoptotic index compared to the control subgroups was found (table 1).

Table 1. Morphometric indicators of laboratory mice liver on the 1st day after resection, $\pm \mathrm{m}, \mathrm{n}=7$

\begin{tabular}{|c|c|c|c|c|}
\hline \multirow[t]{3}{*}{ Indicators } & \multicolumn{4}{|c|}{ Value } \\
\hline & \multicolumn{2}{|c|}{ Mature } & \multicolumn{2}{|c|}{ Old } \\
\hline & $\mathrm{NaCl}$ & MMSC+HSC & $\mathrm{NaCl}$ & MMSC+HSC \\
\hline $\begin{array}{c}\text { Number of } \\
\text { hepatocytes per } 1 \\
\mathrm{~mm}^{2}\end{array}$ & $1192.0 \pm 89.43^{*}$ & $1151.29 \pm 108.24^{*}$ & $1021.0 \pm 91.71^{\circ}$ & $949.14 \pm 86.12^{\circ}$ \\
\hline $\begin{array}{c}\text { Area of hepatocytes, } \\
\mu \mathrm{m}^{2}\end{array}$ & $340.20 \pm 24.43 *$ & $346.43 \pm 26.78$ & $360.70 \pm 30.80^{\circ}$ & $363.99 \pm 23.24^{\circ}$ \\
\hline $\begin{array}{l}\text { Hepatocyte nucleus } \\
\text { area, } \mu \mathrm{m}^{2}\end{array}$ & $81.64 \pm 7.45 *$ & $85.26 \pm 6.22$ & $77.59 \pm 6.53^{\circ}$ & $75.54 \pm 6.02^{\circ}$ \\
\hline $\begin{array}{l}\text { Area of hepatocyte } \\
\text { cytoplasm, } \mu \mathrm{m}^{2}\end{array}$ & $258.56 \pm 17.02 *$ & $261.17 \pm 28.97$ & $225.07 \pm 20.25$ & $251.34 \pm 28.32$ \\
\hline $\mathrm{NCI}$ & $0.32 \pm 0.01 *$ & $0.33 \pm 0.06$ & $0.35 \pm 0.01^{\circ}$ & $0.31 \pm 0.06^{\circ}$ \\
\hline $\begin{array}{l}\text { Number of binuclear } \\
\text { hepatocytes per } \mathrm{mm}^{2}\end{array}$ & $334.31 \pm 12.30 *$ & $345.14 \pm 11.59$ & $310.74 \pm 28.49^{\circ}$ & $320.56 \pm 22.72^{\circ}$ \\
\hline MI, \%o & $0.52 \pm 0.03$ & $0.52 \pm 0.03$ & $0.42 \pm 0.03$ & $0.41 \pm 0.03$ \\
\hline AI, \%o & $0.90 \pm 0.06^{*}$ & $0.67 \pm 0.07 * * *$ & $1.08 \pm 0.15^{\circ}$ & $0.86 \pm 0.06^{\circ} \circ \circ$ \\
\hline $\begin{array}{c}\text { Number of } \\
\text { hepatocytes with } \\
\text { micronucleus, \%o }\end{array}$ & $2.23 \pm 0.21$ & $2.27 \pm 2.21$ & $3.23 \pm 0.23$ & $3.19 \pm 0.24$ \\
\hline Liver weight, $g$ & $0.82 \pm 0.07 *$ & $0.91 \pm 0.08 *$ & $0.64 \pm 0.05^{\circ}$ & $0.70 \pm 0.07^{\circ}$ \\
\hline
\end{tabular}

Note: * difference from the intact subgroup of mature laboratory animals, reliable with $\mathrm{p}<0.05 ; * *$ difference from the control subgroup of mature laboratory animals, reliable with $\mathrm{p}<0.05$. $^{\circ}$ difference from the intact subgroup of old laboratory animals, reliable with $\mathrm{p}<0.05 ;{ }^{\circ}$ difference from the control subgroup of old laboratory animals, reliable with $\mathrm{p}<0.05$.

On the 3rd day after liver resection, an increase in the area of the hepatocyte nucleus was observed in animals injected with MMSC and HSC, which led to an increase in the nuclear cytoplasmic index, an increase in the number of binuclear cells. Apoptotic index decrease was also observed in both age groups. Unlike older ones, mature mice had an increase in the mitotic index. This has affected increased liver mass in mature animals (Table 2). 
Table 2. Morphometric indicators of laboratory mice liver on the 3rd day after liver resection, $\mathrm{M} \pm \mathrm{m}$, $\mathrm{n}=7$

\begin{tabular}{|c|c|c|c|c|}
\hline \multirow[t]{3}{*}{ Indicators } & \multicolumn{4}{|c|}{ Value } \\
\hline & \multicolumn{2}{|c|}{ Mature } & \multicolumn{2}{|c|}{ Old } \\
\hline & $\mathrm{NaCl}$ & MMSC+HSC & $\mathrm{NaCl}$ & $\mathrm{MMSC}+\mathrm{HSC}$ \\
\hline $\begin{array}{c}\text { Number of } \\
\text { hepatocytes per } 1 \\
\mathrm{~mm}^{2}\end{array}$ & $1206.72 \pm 91.96^{*}$ & $1160.0 \pm 113.14 *$ & $996.42 \pm 76.65^{\circ}$ & $1009.71 \pm 95.96^{\circ}$ \\
\hline $\begin{array}{c}\text { Area of } \\
\text { hepatocytes, } \mu \mathrm{m}^{2}\end{array}$ & $331.81 \pm 24.02 *$ & $333.43 \pm 18.20^{*}$ & $379.31 \pm 32.58^{\circ}$ & $373.11 \pm 26.87^{\circ}$ \\
\hline $\begin{array}{c}\text { Hepatocyte } \\
\text { nucleus area, } \\
\mu^{2}\end{array}$ & $67.13 \pm 7.01^{*}$ & $84.29 \pm 8.61 * * *$ & $76.01 \pm 8.56^{\circ}$ & $96.93 \pm 9.34^{\circ} \circ \circ$ \\
\hline $\begin{array}{c}\text { Area of } \\
\text { hepatocyte } \\
\text { cytoplasm, } \mu \mathrm{m}^{2}\end{array}$ & $243.64 \pm 19.25$ & $249.14 \pm 9.84$ & $261.57 \pm 24.08$ & $276.19 \pm 17.53$ \\
\hline NCI & $0.27 \pm 0.01^{*}$ & $0.34 \pm 0.02 * * *$ & $0.29 \pm 0.01^{\circ}$ & $0.35 \pm 0.01^{\circ} \circ \circ$ \\
\hline $\begin{array}{c}\text { Number of } \\
\text { binuclear } \\
\text { hepatocytes per } \\
\mathrm{mm}^{2}\end{array}$ & $380.97 \pm 10.15 *$ & $484.0 \pm 35.71 * * *$ & $343.43 \pm 25.8^{\circ}$ & $411.00 \pm 32.0^{\circ \circ}$ \\
\hline MI, \%о & $8.1 \pm 0.60^{*}$ & $10.03 \pm 0.75 * * *$ & $2.81 \pm 0.27^{\circ}$ & $3.15 \pm 0.25^{\circ}$ \\
\hline AI, \%o & $2.13 \pm 0.20^{*}$ & $1.54 \pm 0.15 * * *$ & $2.29 \pm 0.20^{\circ}$ & $1.78 \pm 0.15^{\circ} \circ \circ$ \\
\hline $\begin{array}{c}\text { Number of } \\
\text { hepatocytes with } \\
\text { micronucleus, \%o }\end{array}$ & $3.37 \pm 0.26^{*}$ & $2.97 \pm 0.20^{*}$ & $5.11 \pm 0.44^{\circ}$ & $4.63 \pm 0.33^{\circ}$ \\
\hline Liver weight, $\mathrm{g}$ & $1.25 \pm 0.09 *$ & $1.52 \pm 0.11 * * *$ & $1.04 \pm 0.09^{\circ}$ & $1.17 \pm 0.10^{\circ}$ \\
\hline
\end{tabular}

Note: $*$ difference from the intact subgroup of mature laboratory animals, reliable with $\mathrm{p}<0.05 ; * *$ difference from the control subgroup of mature laboratory animals, reliable with $\mathrm{p}<0.05$; ** difference to control subgroup of mature laboratory animals, reliable with $\mathrm{p}<0.05 .^{\circ}$ difference from the intact subgroup of old laboratory animals, reliable with $\mathrm{p}<0.05 ;{ }^{\circ}$ difference from the control subgroups of old laboratory animals, reliable with $\mathrm{p}<0.05$.

In the experimental group, an increase in the hepatocytes' nucleus area, increase in NCI and in the number of biconuclear cells was observed in the morphometric indicators analysis of mature and old laboratory mice on the 7th day after liver resection against the background of the MMSC and HSC introduction. These changes led to liver mass recovery. When estimating the number of hepatocytes with micronucleus, a decrease in cytogenetically altered cells was found on the background of combined MMSC and HSC transplantation in both age groups. In older laboratory animals, unlike mature ones, there was no increase in mitotic activity (Table 3 ).

Table 3. Morphometric indicators of laboratory mice liver on the 7 th day after liver resection, $\mathrm{M} \pm \mathrm{m}$, $\mathrm{n}=7$

\begin{tabular}{|c|c|c|c|c|}
\hline \multirow{2}{*}{ Indicators } & \multicolumn{4}{|c|}{ Value } \\
\cline { 2 - 5 } & $\mathrm{NaCl}$ & MMSC+HSC & $\mathrm{NaCl}$ & MMSC+HSC \\
\cline { 2 - 5 } & $1427.71 \pm 116.98$ & $1354.0 \pm 138.0$ & $1009.57 \pm 74.49^{\circ}$ & $954.14 \pm 87.02^{\circ}$ \\
\hline $\begin{array}{c}\text { Number of } \\
\text { hepatocytes per 1 } \\
\mathrm{mm}^{2}\end{array}$ & $286.41 \pm 22.44$ & $292.57 \pm 20.94$ & $348.19 \pm 28.36^{\circ}$ & $351.80 \pm 21.06^{\circ}$ \\
\hline $\begin{array}{c}\text { Area of } \\
\text { hepatocytes, } \mu \mathrm{m}^{2}\end{array}$ & $63.39 \pm 5.12 *$ & $80.36 \pm 7.08^{* * *}$ & $72.77 \pm 10.32^{\circ}$ & $97.59 \pm 8.04^{\circ} \circ 0$ \\
\hline $\begin{array}{c}\text { Hepatocyte } \\
\text { nucleus area, } \mu \mathrm{m}^{2}\end{array}$ & & & & \\
\hline
\end{tabular}




\begin{tabular}{|c|c|c|c|c|}
\hline $\begin{array}{c}\text { Area of } \\
\text { hepatocyte } \\
\text { cytoplasm, } \mu \mathrm{m}^{2}\end{array}$ & $223.03 \pm 17.97$ & $212.21 \pm 13.88$ & $227.13 \pm 15.37$ & $254.21 \pm 13.16$ \\
\hline NCI & $0.29 \pm 0.02^{*}$ & $0.38 \pm 0.02^{* * *}$ & $0.32 \pm 0.02^{\circ}$ & $0.38 \pm 0.01^{\circ \circ}$ \\
\hline $\begin{array}{c}\text { Number of } \\
\text { binuclear } \\
\text { hepatocytes per } \\
\mathrm{mm}^{2}\end{array}$ & $320.77 \pm 10.64^{*}$ & $\begin{array}{c}404.71 \pm 27.47^{*} \\
* *\end{array}$ & $305.74 \pm 22.52^{\circ}$ & $381.76 \pm 24.09^{\circ \circ}$ \\
\hline MI, \%o & $4.51 \pm 0.47^{*}$ & $5.80 \pm 0.37^{* * *}$ & $1.50 \pm 0.10^{\circ}$ & $1.66 \pm 0.14^{\circ}$ \\
\hline AI, \%o & $1.25 \pm 0.09^{*}$ & $0.89 \pm 0.08^{* * *}$ & $1.81 \pm 0.17^{\circ}$ & $1,39 \pm 0.13^{\circ}$ ०० \\
\hline $\begin{array}{c}\text { Number of } \\
\text { hepatocytes with } \\
\text { micronucleus, \%o }\end{array}$ & $2.77 \pm 0.23^{*}$ & $2.14 \pm 0.18^{* *}$ & $4.60 \pm 0.37^{\circ}$ & $3.61 \pm 0.24^{\circ \circ}$ \\
\hline Liver weight, g & $1.68 \pm 0.1^{*}$ & $2.12 \pm 0.18^{* *}$ & $1.15 \pm 0.09^{\circ}$ & $1.40 \pm 0.09^{\circ \circ}$ \\
\hline
\end{tabular}

Note: $*$ difference from the intact subgroup of mature laboratory animals, reliable with $\mathrm{p}<0.05$; ** difference from the control subgroup of mature laboratory animals, reliable with $\mathrm{p}<0.05$; ** difference to control subgroup of mature laboratory animals, reliable with $\mathrm{p}<0.05 ;^{\circ}$ difference from the intact subgroup of old laboratory animals, reliable with $\mathrm{p}<0.05 ;{ }^{\circ}$ difference from the control subgroups of old laboratory animals, reliable with $\mathrm{p}<0.05$.

\section{Conclusions}

Thus, the obtained results showed cellular and intracellular regeneration activation in mature laboratory animals and activation of only intracellular regeneration in older animals. In mature animals, increased cellular regeneration is achieved by increasing mitotic activity and inhibiting programmed cell death. Activation of intracellular regeneration in both studied age groups is due to an increase in the binuclear hepatocytes number, an increase in NCI. Identified features of the combined MMSC and HSC transplantation influence on regenerator processes in the liver may be due to changes in liver regeneration during aging. Stem cell homing is known to decrease during aging, their ability to differentiate is reduced, as well as sensitivity to growth factors [1, 11]. Conducted studies allowed to establish inhibition of programmed cell death and hepatocytes mutagenic activity in mature and old laboratory animals after MMSC and HSC co-transplantation.

The obtained data indicate the possibility of combined MMSC and HSC transplantation to activate liver regeneration in mature and old organism under subtotal resection conditions.

\section{References}

1. N. A. Timchenko, Trends in Endocrinology \& Metabolism, 4 (20), 171-176 (2009)

2. G. K. Michalopoulos, J. Cell Physiol, 213 (2), 286-300 (2007)

3. R. A. B. Nucci, A. C. S. Teodoro, E. F. Gama, Morphol. Sci., 33 (4), 179-182 (2016)

4. C. Hu, Journal of Cellular and Molecular Medicine, 22 (3), 1428-1442 (2018)

5. I. Yu. Maklakova, D. Yu. Grebnev, A. P. Yastrebov, Pathological physiology and experimental therapy, 59 (4), 82-86 (2015)

6. S. V. Sazonov, Bulletin of Ural Medical Academic Science, 1, 91-94 (2007)

7. A. A. Gumerova, A. K. Shafigullina, A. A. Trondin, I. M. Gazizov, D. I. Andreeva, M. S. Kaligin, A. A. Rizvanov, A. P. Kiasov, Cell transplantology and tissue engineering, 6 (4), 72-81 (2011)

8. C. Yin, K. J. Evason, K. Asahina, D. Y. Stainier, Journal of Clinical Investigation, 123 (5), 1902-1910 (2013) 
9. C. Kordes, I. Sawitza, S. Gotze, D. Herebian, Journal of Clinical Investigation, 124 (12), 5503-5515 (2014)

10. C. Mitchell, H. Willenbring, Nature protocols, 3 (7), 1167-1171 (2008) doi: 10.1038 /nprot.2014.122

11. H. Gilgenkrantz A. C. de l'Hortet, The American Journal of Pathology, 188 (6), 13161327 (2018) 